\title{
The long-term forecasting of specific fuel consumption by the power system of Uzbekistan
}

\author{
Denis $\operatorname{Losev}^{1 *}$ \\ ${ }^{1}$ Joint-stock company «National electric networks of Uzbekistan», National Dispatch Center, Istiklol - 6, \\ Tashkent, 100000, Uzbekistan
}

\begin{abstract}
The article considers the possibility of using the least squares method (LSM) for long-term forecasting of the parameters of the regime of electric power systems. There is presented least squares method for predicting the parameters of the regime of electric power systems. It is shown that, based on the least-squares method, it is possible to obtain prognostic equations, as well as coefficients of approximating functions necessary for the formation of these equations. The results of the analysis of the comparison of linear, hyperbolic, logarithmic, exponential and quadratic functions on the use of LSMs to predict specific fuel consumption are presented. The criterion of the least squares method, which is according for using the statistical data of the control sample in the obtained prognostic functions, the standard deviations are found.
\end{abstract}

\section{Introduction}

The long-term forecasting of the specific fuel consumption for the entire electric power system, the level and nature of consumption is required in order to identify quantitative indicators of the development of energy indicators, the development of the electric network and power transmission networks, and to determine the fuel strategy.

\section{About the long-term forecasting of specific fuel consumption}

The main task of managing the regimes of electric power systems (EPS) is to satisfy the needs of economic sectors and the population with high-quality electric energy and heat in the short and long term at minimum cost, ensuring energy efficiency of their production and consumption [1,6-10].

However, in a transition economy, due to insufficient investment and imperfect technical means of monitoring and accounting for the production and consumption of energy resources, including electricity, this requirement is not always feasible. In this context, the issues of predicting operational parameters, as well as specific consumption for supplied electricity, and in particular, increasing their accuracy, are becoming paramount. Moreover, well-known forecasting models that do not take into account the market, random nature of relationships, in practice, often turn out to be unsuitable for planning and managing EPS modes. In such a situation, for the analysis, modeling and forecasting of operating parameters and characteristics of the electrical system, it is advisable to apply methods of direct construction of models from observational data (statistics). Such methods make it possible to identify implicit cause-effect relationships and patterns hidden in retrospective data and to present them in explicit form of mathematical models [3-4, 1012].

As we know, the management of EPS on the basis of planning (forecasting) is divided into four time levels: long-term (prospective), short-term planning (forecasting), operational and automatic control. At each level, it is necessary to ensure an appropriate balance of energy production and consumption, which requires maximum forecast accuracy.

Long-term forecasting is the first stage of system research and substantiation of the prospects for the development of energy. It calls to outline the area of acceptable and effective development of the country's fuel-energy complex (FEC), can identify possible problems of the situation and bottlenecks in this development, provide targets, a base and the necessary information to deepen and specify studies in developing the energy strategy, general schemes and development programs for regional industrial energy systems, as well as strategic plans for energy 
companies. Long-term forecasts play an important role in the modern preparation of the fundamental scientific section in a wide area of knowledge related to the development of energy [2, 13-15].

Long-term forecasting of specific fuel consumption in the whole electric power system, the level and nature of annual electricity consumption is required in order to identify quantitative indicators of the development of energy capacities, the development of the electric network and power transmission networks, as well as the determination of the fuel strategy.

Specific fuel consumption per $\mathrm{kW} \cdot \mathrm{h}$ of electric energy supplied is one of the main indicators of energy efficiency in the functioning of the electric power industry in Uzbekistan. This parameter refers to the parameters characterizing the long-term (perspective) forecasting, the period of which is from $1-5$ to 20 years. In case of expectation of commissioning of capacities by EPS or design and design changes in the network in the near future, a long-term forecast is made for the cycle "months-quarters-years".

For long-term forecasting based on statistical methods, retrospective statistical information about the parameters and modes of loading of EPS is used. It is based on the apparatus of statistical analysis and forecasting of time series. It should also be noted that in the process of short-term planning of electrical modes, the results obtained from their long-term planning are used, while the solutions are adjusted taking into account the specified circuit-mode conditions. The results of solving the problems of short-term planning of electric modes are transferred to the level of long-term mode control as planned values $[5,15-19]$.

\section{The results of calculation experiments}

Consider the results of long-term forecasting of specific fuel consumption in the electric power system of Uzbekistan using the least squares method (least squares) and compare its computational efficiency. Table 1 shows the values of specific fuel consumption for a number of years for JSC «Uzbekenergo», with the help of which a training sample was compiled (data from 1990-2011) to derive approximating functions and a control sample (data from 2012-2016) that allows checking approximating functions.

Table 1. The values of specific fuel consumption for a number of years for JSC «Uzbekenergo»

\begin{tabular}{|c|c|c|c|c|c|c|c|c|c|}
\hline & \multicolumn{9}{|c|}{ the data of training sample } \\
\hline Years & 1990 & 1991 & 1992 & 1993 & 1994 & 1995 & 1996 & 1997 & 1998 \\
\hline$x_{i}$ & 1 & 2 & 3 & 4 & 5 & 6 & 7 & 8 & 9 \\
\hline$y_{i}$ & 361,5 & 368,4 & 368,6 & 362,5 & 361,2 & 362,7 & 363,4 & 367,7 & 369,8 \\
\hline & \multicolumn{9}{|c|}{ the data of training sample } \\
\hline Years & 1999 & 2000 & 2001 & 2002 & 2003 & 2004 & 2005 & 2006 & 2007 \\
\hline$x_{i}$ & 10 & 11 & 12 & 13 & 14 & 15 & 16 & 17 & 18 \\
\hline$y_{i}$ & 377,1 & 379,5 & 381,9 & 383,3 & 384,5 & 387,7 & 381,0 & 377,6 & 375,0 \\
\hline \multicolumn{5}{|c|}{ the data of training sample } & \multicolumn{5}{|c|}{ the data of control sample } \\
\hline Years & 2008 & 2009 & 2010 & 2011 & 2012 & 2013 & 2014 & 2015 & 2016 \\
\hline$x_{i}$ & 19 & 20 & 21 & 22 & 23 & 24 & 25 & 26 & 27 \\
\hline$y_{i}$ & 380,8 & 383,6 & 379,8 & 378,9 & 379,9 & 374,2 & 375,6 & 374,8 & 375,0 \\
\hline
\end{tabular}


In order to determine approximating coefficients of prognostic equations from systems of equations obtained for [6]:

- linear function (LSM-1),

- hyperbolic function (LSM-2),

- logarithmic function (LSM-3),

- exponential function (LSM-4),

- quadratic functions (LSM-5).

We will make the necessary calculations and, according to the criterion of the least squares method (LSM) (1), we determine an approximating function whose sum of the squared deviations is the smallest:

$$
\sum_{i=1}^{n} e_{i}^{2}=\sum_{i=1}^{n}\left(y_{i}-f\left(x_{i}\right)\right)^{2} \rightarrow \min .
$$

Assume all points M1(x1,y1), M2(x2,y2),.., $\mathrm{Mn}(\mathrm{xn}, \mathrm{yn})$ tend to be in a straight line and there is every reason to believe the presence of a linear relationship:

$$
\mathrm{y}=\mathrm{f}(\mathrm{x})=\mathrm{ax}+\mathrm{b} .
$$

Find the coefficients $a$ and $b$ so that the sum of the squared deviations

$$
F(a, b)=\sum_{i=1}^{n} e_{i}^{2}=\sum_{i=1}^{n}\left(y_{i}-\left(a x_{i}+b\right)\right)^{2}
$$

was the smallest. To do this, we find partial derivatives of the first order. According to the rule of linearity, you can differentiate directly under the sum icon:

$$
\begin{aligned}
& \frac{\partial F}{\partial a}=\left(\sum_{i=1}^{n}\left(y_{i}-\left(a x_{i}+b\right)\right)^{2}\right)_{a}= \\
& \sum_{i=1}^{n}\left[2\left(y_{i}-\left(a x_{i}+b\right)\right) \cdot\left(y_{i}-\left(a x_{i}+b\right)\right)_{a}\right]= \\
& \left.2 \sum_{i=1}^{n}\left[\left(y_{i}-a x_{i}-b\right)\right) \cdot\left(0-\left(x_{i}+0\right)\right)\right]= \\
& \left.2 \sum_{i=1}^{n}\left[\left(y_{i}-a x_{i}-b\right)\right) \cdot\left(-x_{i}\right)\right]= \\
& 2 \sum_{i=1}^{n}\left[\left(a x_{i}^{2}+b x_{i}-y_{i} x_{i}\right)\right] \\
& \frac{\partial F}{\partial b}=\left(\sum_{i=1}^{n}\left(y_{i}-\left(a x_{i}+b\right)\right)^{2}\right)_{b}= \\
& \sum_{i=1}^{n}\left[2\left(y_{i}-\left(a x_{i}+b\right)\right) \cdot\left(y_{i}-\left(a x_{i}+b\right)\right)_{b}\right]= \\
& \left.2 \sum_{i=1}^{n}\left[\left(y_{i}-a x_{i}-b\right)\right) \cdot(0-(0+1))\right]= \\
& 2 \sum_{i=1}^{n}\left[\left(a x_{i}^{2}+b-y_{i}\right)\right]
\end{aligned}
$$

We compose a standard system of equations:

$$
\left\{\begin{array} { l } 
{ \frac { \partial F } { \partial a } = 0 } \\
{ \frac { \partial F } { \partial b } = 0 }
\end{array} \Rightarrow \left\{\begin{array}{l}
2 \sum_{i=1}^{n}\left[\left(a x_{i}^{2}+b x_{i}-y_{i} x_{i}\right)\right]=0 \\
2 \sum_{i=1}^{n}\left(a x_{i}^{2}+x_{i}-y_{i}\right)=0
\end{array}\right.\right.
$$

After simplification, the system of equations will have the following form:

$$
\begin{aligned}
& \left\{\begin{array}{l}
a \sum_{i=1}^{n} x_{i}^{2}+b \sum_{i=1}^{n} x_{i}-\sum_{i=1}^{n} y_{i} x_{i}=0 \\
a \sum_{i=1}^{n} x_{i}+\sum_{i=1}^{n} b-\sum_{i=1}^{n} y_{i}=0
\end{array} \Rightarrow\right. \\
& \left\{\begin{array}{l}
a \sum_{i=1}^{n} x_{i}^{2}+b \sum_{i=1}^{n} x_{i}-\sum_{i=1}^{n} y_{i} x_{i}=0 \\
a \sum_{i=1}^{n} x_{i}+\sum_{i=1}^{n} p+4{ }_{2}+4 \cdot 3 b-\sum_{i=1}^{n} y_{i}=0
\end{array}\right.
\end{aligned}
$$

We rewrite the system in the "applied" form:

$$
\left\{\begin{array}{l}
a \sum_{i=1}^{n} x_{i}^{2}+b \sum_{i=1}^{n} x_{i}=\sum_{i=1}^{n} y_{i} x_{i} \\
a \sum_{i=1}^{n} x_{i}+b n=\sum_{i=1}^{n} y_{i}
\end{array}\right.
$$

If a function is assumed in the form of hyperbolic (8), logarithmic (9), exponential (10) and quadratic (11), having performed similar calculations (3-7), the system of equations will have the following form:

$$
\begin{aligned}
& \left\{\begin{array} { l } 
{ \frac { \partial F } { \partial a } = 0 } \\
{ \frac { \partial F } { \partial b } = 0 }
\end{array} \Rightarrow \left\{\begin{array}{l}
a \sum_{i=1}^{n} \frac{1}{x_{i}^{2}}+b \sum_{i=1}^{n} \frac{1}{x_{i}}=\sum_{i=1}^{n} \frac{y_{i}}{x_{i}} \\
a \sum_{i=1}^{n} \frac{1}{x_{i}}+b n=\sum_{i=1}^{n} y_{i}
\end{array}\right.\right. \\
& \left\{\begin{array} { l } 
{ \frac { \partial F } { \partial a } = 0 } \\
{ \frac { \partial F } { \partial b } = 0 }
\end{array} \Rightarrow \left\{\begin{array}{l}
a \sum_{i=1}^{n} \ln \left(x_{i}\right)^{2}+b \sum_{i=1}^{n} \ln \left(x_{i}\right)=\sum_{i=1}^{n} y_{i} \ln \left(x_{i}\right) \\
a \sum_{i=1}^{n} \ln x_{i}+b n=\sum_{i=1}^{n} y_{i}
\end{array}\right.\right. \\
& \left\{\begin{array} { l } 
{ \frac { \partial F } { \partial a } = 0 } \\
{ \frac { \partial F } { \partial b } = 0 }
\end{array} \Rightarrow \left\{\begin{array}{l}
a \sum_{i=1}^{n} x_{i}^{2}+b \sum_{i=1}^{n} x_{i}=\sum_{i=1}^{n} x_{i} \ln \left(y_{i}\right) \\
a \sum_{i=1}^{n} x_{i}+b n=\sum_{i=1}^{n} \ln \left(y_{i}\right)
\end{array}\right.\right.
\end{aligned}
$$




$$
\begin{aligned}
& \frac{\partial F}{\partial a}=0 \quad\left(a \sum_{i=1}^{n} x_{i}^{4}+b \sum_{i=1}^{n} x_{i}^{3}+c \sum_{i=1}^{n} x_{i}^{2}=\sum_{i=1}^{n} x_{i}^{2} y_{i}\right. \\
& \left\{\frac{\partial F}{\partial b}=0 \Rightarrow\left\{a \sum_{i=1}^{n} x_{i}^{3}+b \sum_{i=1}^{n} x_{i}^{2}+c \sum_{i=1}^{n} x_{i}=\sum_{i=1}^{n} x_{i} y_{i}\right.\right. \\
& \frac{\partial F}{\partial c}=0 \quad a \sum_{i=1}^{n} x_{i}^{2}+b \sum_{i=1}^{n} x_{i}+c n=\sum_{i=1}^{n} y_{i}
\end{aligned}
$$

Based on the data of the training sample, solving the system of equations (7-11) we determine the coefficients with which we will form the following prognostic functions (12-16) LSM-1, LSM-2, LSM-3, LSM-4 and LSM-5, respectively: $\mathrm{y}=\mathrm{f}(\mathrm{x})=1,040373 \mathrm{x}+362,4039$

$\mathrm{y}=\mathrm{f}(\mathrm{x})=-23,1112 / \mathrm{x}+378,2454$

$\mathrm{y}=\mathrm{f}(\mathrm{x})=-6,35941 * \ln (\mathrm{x})+389,3322$

$\mathrm{y}=\mathrm{f}(\mathrm{x})=366,12 * \mathrm{e} 0,0016 \mathrm{x}$

$\mathrm{y}=\mathrm{f}(\mathrm{x})=-0,0624 \mathrm{x} 2+2,4745 \mathrm{x}+356,67$

Based on the control sample, using (12-16), we predict the specific consumption from 2012 to 2016.

Table 2. The calculation results (in ton of standard fuel).

\begin{tabular}{|c|c|c|c|c|c|c|}
\hline Years & Fact & LSM-1 & LSM-2 & LSM-3 & LSM-4 & LSM-5 \\
\hline 2012 & 379,9 & 386,33 & 376,9 & 369,39 & 379,6 & 380,57 \\
\hline 2013 & 374,2 & 387,37 & 376,9 & 369,12 & 380,6 & 380,12 \\
\hline 2014 & 375,6 & 388,41 & 377,0 & 368,86 & 381,7 & 379,53 \\
\hline 2015 & 374,8 & 389,45 & 377,0 & 368,61 & 382,8 & 378,82 \\
\hline 2016 & 375,0 & 390,49 & 377,0 & 370,35 & 383,8 & 377,99 \\
\hline
\end{tabular}

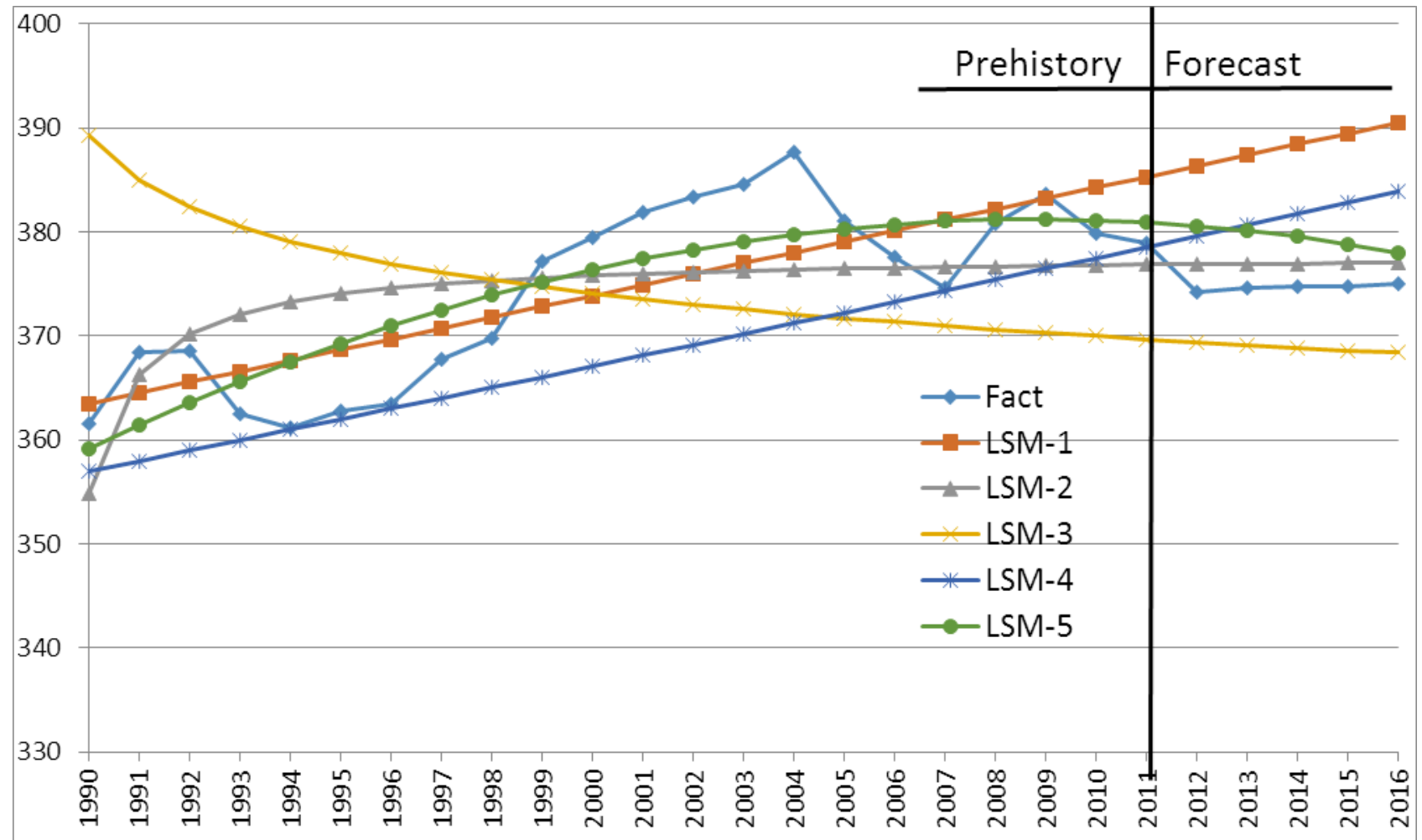

Fig. 1. Graphs comparing the forecast for specific fuel consumption in the period 2012-2016 (in ton of standard fuel). 


\section{Conclusion}

According to the least squares least squares criterion, the least sum of squared deviations was obtained when predicting the quadratic function (LSM-5):

$$
\begin{gathered}
\sum_{i=1}^{n} e_{i L S M-3}^{2} \phi \sum_{i=1}^{n} e_{i L S M-2}^{2} \phi \sum_{i=1}^{n} e_{i}^{2}{ }_{L S M-4} \phi \sum_{i=1}^{n} e_{i}^{2}{ }_{L S M-1} \phi \sum_{i=1}^{n} e_{i}^{2}{ }_{L S M-5} \\
3619,7 \phi 1031,1 \phi 825,4 \phi 593,9 \phi 483,7
\end{gathered}
$$

Thus, in conclusion, it should be noted that from the analyzed functions according to the LSM criterion, the least sum of squared deviations was obtained when predicting specific fuel consumption using a polynomial 2-degree function.

\section{References}

1. Allaev K.R., Basidov I.S., Sadullaev E.F. Elektroenergetika Uzbekistana za gody Nezavisimosti i perspektivy yeyo razvitiya. -T. Ishoch, 2016, -273 s.

2. Kononov Yu.D. Puti povysheniya obosnovannosti dolgosrochnyx prognozov razvitiya TEK - Novosibirsk: Nauka, 2015, -147 s.

3. Allaev K.R. Elektroenergetika Uzbekistana i mira. -T. «Fan va texnologiya», 2009, -464 s.

4. Allaev K.R. Energetika mira i Uzbekistana. T.: Moliya, 2007, $-388 \mathrm{~s}$.

5. Ivakhnenko A.G. Dolgosrochnoe prognozirovaniye i upravleniye slojnymi sistemami. Kiyev: Texnika, 1975, -311 s.

6. Uzenergy.uzpak.uz.sjsc@uzpak.uz Khamidov SH.V. Elektroenergetika Respubliki Uzbekistan sostoyaniye, perspektivy razvitiya i investitsionnyy klimat. Doklad na Biznes - forume v Parizhe (20-23 iyunya 2006 goda), $-28 \mathrm{~s}$.

7. Buranov I. Perspektivy povysheniya energoeffektivnosti Respubliki Uzbekistan. T.// Problemy energo- i resursosberezheniya, 2014. №4, S. 20-29.

8. Bikeyeva E.R. Strategicheskiye napravleniya i prioritety razvitiya elektroenergetiki Uzbekistana $\mathrm{V}$ dolgosrochnoy perspektive. T.// Problemy energo- i resursosberezheniya, 2015. №1-2, S. 10-18.

9. Shoismatov E.R. Zadachi energosberezheniya i puti ix resheniya $\mathrm{v}$ elektroenergeticheskoy otrasli strany. TGTU. //Problemy energo- i resursosberezheniya, 2003. №1-2, S. 44-54.

10. Zakhidov R.A. Osnovnyye napravleniya energosberezheniya $\mathrm{V}$ otraslyakh ekonomiki Uzbekistana. -T. TGTU.// Problemy energo- i resursosberezheniya, 2005. №4, S. 10-19.

11. Teshabayev B.M. Povysheniye energoeffektivnosti elektroenergetiki Uzbekistana. T. diss. uchen. step. k.t.n., 2009. -174 s.

12. Ayuyev B.I. Upravleniye elektropotrebleniyem: administrativnyye i ekonomicheskiye metody// Energorynok, 2007. №4. $25 \mathrm{~s}$.

13. Gitel'man L.D., Ratnikov B.Ye., Kozhevnikov M.V. Upravleniye sprosom - universal'nyy metod resheniya sovremennykh problem elektrosnabzheniya// Energorynok, 2012. №5, S. 44-49.

14. Allayev K.R., Bikeyeva E.R. Energetika osnova razvitiya ekonomiki Uzbekistana. T.// Problemy energo- i resursosberezheniya, 2008. №1-2, S. 12-29.

15. Ol'khovskiy G.G. Global'nyye problemy energetiki. M.// Elektricheskiye stantsii, 2005. №1, S. 4-10.

16. Teshabayev B.M. Energosbrazheniya-osnova energoeffektivnosti. T.//Problemy energo- i resursosberezheniya, 2007. №1, S.10-16.

17. Teshabayev B.M. Voprosy effektivnosti proizvodstva, peredachi i raspredeleniya elektroenergii v Uzbekistan: sushchestvuyushchaya praktika i novyye podkhody. /Materialy Mezhdunarodnoy konferentsii «Zakonodatel'nyye osnovy ratsional'nogo ispol'zovaniya energii i reformirovaniya elektroenergetiki», Tashkent, 2006. S.30-40.

18. Chernysh Yu.V. Mirovoy opyt reformirovaniya elektroenergetiki. -M. MGU. Avtoreferat na sois. k.e.n., 2013. -24 s.

19. http://www.rao-ees.ru. Zarubezhnyy opyt reformirovaniya elektroenergetiki. 